This item was submitted to Loughborough's Research Repository by the author.

Items in Figshare are protected by copyright, with all rights reserved, unless otherwise indicated.

\title{
Becoming a Viking: DNA testing, genetic ancestry and placeholder identity
}

PLEASE CITE THE PUBLISHED VERSION

http://dx.doi.org/10.1080/01419870.2016.1105991

\section{PUBLISHER}

(c) Taylor \& Francis

\section{VERSION}

AM (Accepted Manuscript)

\section{PUBLISHER STATEMENT}

This work is made available according to the conditions of the Creative Commons Attribution-NonCommercialNoDerivatives 4.0 International (CC BY-NC-ND 4.0) licence. Full details of this licence are available at: https://creativecommons.org/licenses/by-nc-nd/4.0/

\section{LICENCE}

CC BY-NC-ND 4.0

\section{REPOSITORY RECORD}

Scully, Marc D., Steven D. Brown, and Turi King. 2019. "Becoming a Viking: DNA Testing, Genetic Ancestry and Placeholder Identity”. figshare. https://hdl.handle.net/2134/19565. 


\section{Becoming a Viking: DNA Testing, genetic ancestry and placeholder identity}

Marc Scully*, Steven D. Brown** and Turi King***.

* Department of Social Sciences, University of Loughborough, Loughborough, United Kingdom.

** School of Management, University of Leicester, Leicester, United Kingdom.

*** Department of Genetics, University of Leicester, Leicester, United Kingdom.

\section{Abstract}

A consensus has developed among social and biological scientists around the problematic nature of genetic ancestry testing, specifically that its popularity will lead to greater genetic essentialism in social identities. Many of these arguments assume a relatively uncritical engagement with DNA, under 'high-stakes' conditions. We suggest that in a biosocial society, more pervasive 'low-stakes' engagement is more likely. Through qualitative interviews with participants in a study of the genetic legacy of the Vikings in Northern England, we investigate how genetic ancestry results are discursively worked through. The identities formed in 'becoming a Viking' through DNA are characterised by fluidity and reflexivity, rather than essentialism. DNA results are woven into a wider narrative of selfhood relating to the past, the value of which lies in its potential to be passed on within families. While not unproblematic, the relatively banal nature of such narratives within contemporary society is characteristic of the 'biosociable'.

\section{Keywords:}

Popular science; biosocial; Viking ancestry; Applied Genetic History; Essentialism; Identity 


\section{Becoming a Viking: DNA Testing, genetic ancestry and placeholder identity ${ }^{1}$}

\section{Introduction}

Social scientists have become increasingly aware of how contemporary conceptual and technological innovations within the life sciences have begun to reformulate the category of the social, renewing the notion of a 'biosocial' domain of enquiry (Meloni, 2014 ; Ingold \& Palsson, 2013; Rose 2013). One of the central issues here is that not only is it no longer the sole business of social scientists to define and analyse 'the social', but moreover that the very meaning and negotiation of matters like class, family, ancestry and belonging is now happening within contemporary societies through a direct engagement of citizens with practices such as personalized medicine, neurological enhancement and genetic ancestry testing (Schramm, Skinner \& Rottenburg, 2012). This latter practice offers particular challenges since it seems to hold the promise, to users, of facilitating biological connections with distant populations and places, giving scientific weight to identification (Nordgren \& Juengst, 2009). Small wonder that this apparent capacity to unsettle the past has critics bemoaning the unwelcome return of 'race' into the social sciences (Morning, 2014).

Population geneticists are themselves extremely wary of the claims made for what genetics can and cannot do. As Jobling et al (this volume) explain, linking a given individual to a specific ancestral group involves cautious speculation on the balance of probabilities (see also Balding et al, 2013). Similarly, Thomas (2013) has refuted the idea of making straightforward claims to lineage, as promoted by commercial genetic ancestry testing companies, as in effect 'genetic astrology', a term that has gained currency in 'skeptic' circles. But these authoritative and informed claims about what genetics can and cannot do are to some extent distinct from the actual 'on the ground' practices of civil engagement with genetic ancestry testing services. Sommer (2012a) has elegantly critiqued the meditational process at work in 'applied genetic history', whereby the science of population genetics is presented by stakeholders as though it were a straightforward route of providing individuals with personally tailored information about their likely ancestry. Other critiques have focussed on how popular media (generally books and television) and genetic ancestry testing companies have often collaborated to encourage the belief that it is possible to read an individual's DNA in such a way as to create a personal link with specific groups in the past. Examples of such critiques include Fortier's (2011) analysis of the Channel 4 documentary Face of Britain, Nash's analysis (2004) of the BBC Radio 4 series Surnames, Genes and Genealogy, and Nelson (2008) on the BBC documentary, Motherland: a Genetic Journey.

\footnotetext{
${ }^{1}$ CONTACT Marc Scully, m.d.scully@lboro.ac.uk, @marcdonnchadh
} 
These critiques have tended to focus on the framing of genetic knowledge in media and popular science accounts. But what this does not necessarily tell us is of the effect this framing has upon its intended audience. How do the potential consumers or participants of genetic ancestry testing interpret and make use of the knowledge they are provided by the service? The 'genetic astrology' critique of the 'just so' stories offered by genetic ancestry testing companies, implicitly represents the users of genetic ancestry data as either entirely credulous, or engaged in an activity that is entirely recreational, even frivolous. Such a representation may not allow for the possibility of a more critical engagement with such data on the part of the public, or indeed the role of individual agency. In this paper, we seek to introduce more nuance to this picture through a social psychological study of individual accounts of 'lay' engagement with personalized genetic data. We address the 'reception' and 'enactment' of genetic knowledge through interviews with participants in an academic study of 'Surnames and the Y Chromosome'. Through quantitative and qualitative data gathered alongside this study, both at the moment of testing, and following the return of DNA results, we are able to explore the representation and expectations this group has of population genetics and show the ways in which the results of genetic testing are incorporated into narratives around ancestry and current identity.

The participants in the study were based in the North of England, with the majority being based in Yorkshire. This is a region of the country where there are strong cultural narratives around the legacy of the Viking raids and presence between the latter part and turn of the first millennium (roughly $793-1066$ ). The legacy is heavily promoted locally, notably in the Jorvik Viking Centre on York's Coppergate, and is subject to considerable reconstruction with a contemporary gloss (Addyman, 1990; Halewood \& Hannam, 2001; Townend 2014). A Jorvik Viking Festival is now held annually in the streets of York, while associations with the Viking past now appear to be an established part of Yorkshire's 'brand identity'; for instance, Yorkshire's One-Day cricket team were recently rebranded as the 'Yorkshire Vikings', with the launch event taking place at the Jorvik Centre. For many participants in the study, possible Viking ancestry is a coveted identity, which has in some cases been subject to family speculation over several generations, and any evidence in support of the claim is a source of strong personal value.

However, the potential claim to Viking origins needs to be seen as one that has comparatively 'low stakes' in comparison to some of the other ancestry claims discussed in the literature. Duster's (2011) incisive analysis demonstrates how genetic ancestry testing holds out the possibility to African-Americans of establishing their place in the complex histories of slavery and colonialism, whilst often proving to be corrosive of extant forms of kinship and association. Duster's examples, 
along with those from Hamilton (2012) and Golbeck and Roth (2012), have relatively 'high stakes', where settling questions of ancestry is entangled with current disputes over rights and benefits. The problem is the manner in which 'applied population genetics' is thought to result in an essentialization (or in some cases re-essentialization) of identity that occludes complex social, political and juridical questions (Brodwin, 2005). Indeed, as Phelan et al. (2014) describe, exposure to media coverage around genetic tests of 'racial admixture' appears to contribute towards beliefs that 'races' are essentially different rather than to challenge traditional racial categories (which have little meaning for contemporary population genetics). However, it is debateable whether this form of essentialization is an inevitable consequence of engaging with 'applied genetic history', or whether the normalization of biosocial practices of engagement is associated with greater levels of nuance and individual agency. As such, attention to 'low stakes' situations may provide a more realistic picture of the future position of 'applied genetic history' in the biosocial. In attending to 'low stakes' conditions, we are also aware that the division between these and 'high-stakes' engagements is not necessarily clear cut; as illustrated by Lee (2013), low-stakes 'recreational' genetic ancestry testing has the capacity to suddenly shift to 'high-stakes' outcomes.

Despite the lack of any substantive gain, participation in the present study nevertheless represented a form of exchange. In return for their 'gift of spit', as Harris et al (2013) describe the saliva sample provided for testing, most participants expected some form of reciprocity. For the majority, this was to learn something about their family history, or 'origins', however partial and inconclusive this might be. This echoes Richard Tutton's $(2002,2004)$ analysis of interviews with Orkney-based participants in the 'European Genome Diversity Project', who saw the donation of their sample (in this case blood rather than saliva) as a way of exploring their family genealogy from a position that was clearly rooted in their current identity as 'Orcadian' with its associated social ties. Similarly, the participants here were all to some degree 'secure' in their local regional identity, but saw the research as being able to extend and enrich the intersection of their family history with their contemporary regional identification (see Scully et al, 2013). But as both Tutton, and Sommer (2012b) show, gaining knowledge that may inform family genealogy is typically not done for purely personal satisfaction. It is knowledge that can be exchanged or 'gifted' to others, notably family members, and in so doing has a role in fostering current family and community bonds.

The question then arises as to how this nested set of exchanges, between researcher and participant and then participant and family/community members, mediates the knowledge gained from genetic testing, and the social actions it accomplishes in the course of this process. Whilst population geneticists seek to aggregate individual DNA results to explore past migrations at a population level 
(Jobling et al., 2014), participants are, arguably, looking for a personalized 'usable' past. In other words, they seek knowledge that may assist them in elaborating or constructing a narrative around the past that has some relevance for understanding the present. This may take the form of knowledge that allows a family tree to be extended beyond the limits of existing record keeping - to find a lineage that goes far beyond five or six generations (see Scully et al, 2013). But since the results of genetic testing concern genetic markers that, taken in isolation, provide little anchoring for other kinds of information, the kinds of narratives that they resource concern what Simpson (2000) calls 'imagined genetic communities'. That is, a representation of collectivity and 'being like us' that has its basis in the effort to elaborate the rather minimal and fragmentary information provided by the results of genetic testing. Here one of the obstacles to constructing a 'usable past' is the complexity of the results themselves, particularly when they are presented in a relatively unmediated form. As Catherine Nash $(2004,2015)$ has eloquently argued, the very idea of 'genetic kinship' is a highly unstable notion that requires enormous situated cultural 'work' to offer any meaning. It does not provide ready-made narratives for participants, and may in fact do precisely the reverse by destabilising existing narratives of past origins.

As our colleagues Jobling et al (this volume) make clear, the 'markers of identity' offered by population genetics are by definition unsuited to the work of fixing individual identity. However, as a body of research has shown, this does not stop the recipients of genetic knowledge in experimenting with creative identification around such markers. For instance, Sommer (2012b) outlines the lighthearted, playful way in which Swiss customers of the iGENEA company engaged with their newlydetermined 'Scottish' or 'Viking' roots. However, she also warns that despite the intentions of either company or consumers, this form of recreational genomics cannot be entirely separated from wider political disputes about Swiss identity and culture. In the same way that for Michael Billig (1995), 'banal' did not necessarily imply 'benign', here too 'playful' does not necessarily imply 'harmless'.

In applying the term 'marker' to this kind of experimentation, it is perhaps best to use the metaphor of a bookmark, or a 'placeholder of identity' that temporarily positions genetic knowledge within narratives of identity. A placeholder is a means of indicating a provisional identity in advance of determining its meaning or utility. As such, it points to the work that is yet to be done, or seeks to keep something in play that might otherwise be lost. For example, in Hurst's (2014) research on genealogical connections in the North-East of England, participants would retain vague or apparently irrelevant information in the hope that it might at some point result in 'adding to the story' (Hurst, 2014, p. 148). Placeholders of identity - such as information on haplogroups - have a kind of deferred status. They may be something of a puzzle for now, or as with Sommer's participants, an 
oddity that provokes humour rather than serious identification, but they nevertheless accrue value within the exchanges between researchers, participants and communities.

The guiding thread for this paper will then be the focus on how the results of genetic testing are mediated through a series of nested exchanges, the constitution of placeholders of identity in the course of constructing usuable personal pasts and the social uses to which genetic knowledge is then put by participants and their families.

\section{Methodology and Context}

The study occurs in the context of Turi's on-going project on 'Surnames \& the Y chromosome', which aims to build a picture of the genetic legacy of the Vikings in Northern England, in relation to surnames that are inherited, like the $Y$ chromosome, through the male line (King \& Jobling, 2009). All participants interviewed by us were first recruited for this current study, which sought men with highly localized, relatively rare, surnames and who had an established genealogical connection to the local region. Sampling sessions were carried out in January 2012 in York, Harrogate, Lancaster and Keswick, following advertisements in local media as well as genealogical websites. At each of these sessions, participants were asked to fill in a participant-motivation survey (see Scully et al 2013 for further details).

Participants were twice provided with information about the wider use to which the data were being put, as well as the necessary caveats about drawing inferences about ancestry from individual DNA results: at the sampling session, and again accompanying the returned results. The information sheet accompanying the results contains a map illustrating the distribution of $Y$-chromosome haplogroups in contemporary Europe, as well as some information about the geographical history of each haplogroup. A haplogroup is a classification of a man's Y-chromosome that is based on mutations (insertions or deletions of DNA and 'single nucleotide polymorphisms' or SNPs) that have occurred in the DNA sequence over generations. There are 20 main haplogroups referred to with letters (e.g. A, B, C etc) based on mutations that occurred thousands of years ago and subdivisions within each group (e.g. R1a, R1b etc) based on more recent mutations. Population geneticists are able to make approximate calculations as to when these mutations occurred, and map their contemporary geographical clustering. Haplogroups R1a and I1 are frequent in Scandinavia, and therefore more likely to have been carried by Viking populations. However the information sheet provided with the study is careful not to suggest that a man with one of these $Y$ chromosome types will definitively have Viking ancestry through the male line. Unlike some commercial companies, individual results are returned but the results are not linked to any historical cultural group, and thus 
not presented as proof of Viking ancestry. The researchers stress that the Y-chromosome only contains information about one strand of genetic ancestry (i.e. that of the male-line only). From Turi's experience, while it is clear that many participants do appreciate the complexities of the research, there are others who see this complexity as an obstacle to direct proof of Viking ancestry.

Participants were asked to supply contact details if they were willing to participate in follow-up interviews after their DNA results had been returned to them. A decision was taken to narrow the focus of this follow-up study to Yorkshire, both for logistical reasons and due to the growing extent to which Yorkshire now trades on its Viking heritage, as previously discussed. After DNA results were returned in June 2013, we approached participants who had attended the sessions in York and Harrogate, and asked them to participate in a follow-up interview. Not all of those who had initially indicated willingness replied; while there may be many reasons for this, it is possible that at least some of those who were disappointed with their results, wanted no more to do with the project. Overall, 18 interviews were conducted between July and December 2013, mostly in participants' own homes in Yorkshire. In the majority of cases, the interviews were carried out on a one-to-one basis, but it was not unusual for family members to be present and occasionally contribute to the conversation. In keeping with the demographic profile of the sampling sessions, participants were mostly men in late middle-age, or past retirement.

Marc conducted the interviews, which were semi-structured. While some were relatively brief, lasting approximately half an hour, the majority lasted an hour or more. Each interview covered the topics of the participants' own interest in family history, local history and the Vikings; their sense of local and national identity as related to their ancestry; their awareness and understanding of population genetics, and their reaction to their results. Analysis, as carried out by Marc and Steve, initially focused on how participants drew on genealogical, genetic and wider socio-cultural resources to position themselves in relation to the past. Below, we have focused specifically on how participants made sense of their results with reference to the potential of being of Viking descent; in particular we were interested in how participants narrate the process of becoming involved in the research, receiving and interpreting their results. We were also interested in how these narratives inform the stories they have told their friends and family members about their 'Viking heritage' (or lack thereof). The question therefore is how the participants' DNA results are rhetorically organized in order to allow them to make claims about their own identities. 


\section{Prior Knowledge: 'This is incredible use of genetic research'}

All of the respondents who took part in the study had some form of prior understanding of genetics, which underpinned their motivation and interest in participating. For the majority, this knowledge was mediated by history and popular science television programmes which featured genetic ancestry testing. In the first extract, Miles makes reference to the BBC TV show Meet the Ancestors:

\section{Extract 1:}

Marc: How did this come onto your radar, the fact that this was something you could get done?

Miles: $\quad$ Oh, erm well, there'd been various programs on the telly. Uh and one that really struck me there was a Meet the Ancestors and they'd found a skull in Dorset or Devon. And it was a village rather like [participant's home village] where people didn't leave. And so they'd found this skull and they'd dated it to two thousand BC. And they had a reconstruction made of the face and they did DNA checks with the villagers who could indicate that their ancestors had been there for some time. And at the end of the program they had this *remarkable* scene, where they got the head on a stand on the stage of the village hall with a cover over it. And they said to all the people in the audience there is somebody who is related to this person. Can Mr so-and-so come up on stage. And so they stood him alongside of this reconstructed head under the cover. And then they took the cover off and they could have been twins. It was absolutely amazing. Over four thousand years. And at the time, I thought, this is incredible use of genetic research. I just got completely fascinated by the idea that uh- and it kind of reinforced what I said earlier about people being essentially the same over long periods of history, $y^{\prime}$ know, they're physically the same and probably have the same ambitions and most people just want a quiet life, bring the kids up, see them doing well, y'know, and that's been the same throughout history, I think.

This particular 'remarkable' scene in a long running series appears to have convinced Miles of the 'incredible' power of genetics to enable authoritative accounts of ancestry stretching back into the deep past ('over four thousand years'). Genetics is here part of an evidential package that includes other forms of evidence, such as archaeological materials and facial reconstruction, which together can demonstrate a direct link to the past. To some extent this understanding of the power of genetics when combined with other techniques is broadly informed by its framing within Meet the Ancestors, where the archaeological excavation of 
human remains was presented in each episode using the narrative tropes of 'cold case' detective mysteries. In the episode in question, the results of genetic testing are delivered as part of a 'reveal' set up, where the past-in-the-present is dramatically revealed. This allows Miles to see himself as part of something like an 'imagined genetic community' that stretches back over thousands of years. However it is noteworthy that whilst genetics is one of the means to uncovering this continuity over time, it does not appear to be the 'essential' property that links Miles to Iron Age Britons. Although Miles proposes that people are 'physically the same', he rapidly adds a list of unvarying social attributes that have persisted over time, such as a desire for a 'quiet life' and to see 'the kids' do well. So rather than arriving at genetic or biological reductionism, it appears that for Miles the application of genetics here leads to a socio-cultural essentialism where prior beliefs in the unchanging nature of those who have dwelt in the same local area across the centuries is enriched or confirmed by genetic ancestry testing. However, respondents were aware that genetic testing could also challenge longstanding convictions around ancestry. In extract 2, Lawrence (accompanied by his daughter Rosemary) refers to the popular genealogy TV programme Who Do You Think You Are?:

\section{Extract 2:}

Lawrence: $\quad$ Well if you watch Who Do You Think You Are you know a lot of them people have got the DNA and thinking they're half this and that and then all of a sudden they get the DNA and they find out they're not you know, ooh that would be interesting, but I still felt that I was you know, I was a northerner and I was, you know, of Viking origin or Scandinavian origin so it's

Rosemary: Well there was that as well wasn't there, there was this, when that came out

Marc: $\quad$ This is the, the Face of Britain

Rosemary: The Face of Britain one which had, it was like, yeah can I get on one of them studies. You were desperate to get on one of them studies, weren't you? How do I get my DNA taken yeah [Lawrence: to prove it] yeah (laughs).

Marc: So when the opportunity came up then you really jumped at, yeah, yeah

Rosemary: We've never heard the last of it for years (laughs). 
Lawrence describes how guests on the programme can find that their established narratives of identity ('thinking they're half this and that') are contradicted by the results of genetic testing. As with many other participants, it is mediation of genetic testing via the framing of the delivery of unequivocal results that attracts his interest. But Lawrence's desire to, as Rosemary puts it, 'get on one of them studies', in order to 'prove' his Viking origins appears to have been heightened rather than moderated by awareness of the possibility of contradictory results. We might describe Lawrence as here expressing something of a 'caveat emptor' approach to participation - he wished to subject his beliefs about his origins to the 'acid test' of genetics. In this way what is being brought forward for testing is not simply Lawrence's genetic ancestry, but rather his beliefs and feelings concerning his Viking origins grounded in his identity as a 'Northerner'. The literal exchange here may be that of saliva for information, but this is in the service of Lawrence gaining potential accreditation for what he feels he already knows. Engaging with the possibility of contradiction adds rhetorical weight to the formulation of Lawrence's claim to 'Viking-ness'. In both extracts then, genetics is not an end in itself, nor presented as a form of biological essentialism, but rather a means to evaluate and potentially enhance a prior socio-cultural essentialism.

\section{Accounts of the session: 'It's not the sort of thing you retain'}

Each of the sessions where samples were taken featured a talk given by Turi, which aimed to introduce participants to the scientific background to the study. This talk also served to manage the expectations of participants with regard to the likely range of outcomes. When asked for their recollections of the session, participants were generally positive about the talk, which served to anchor their impressions of the day as a whole. In extract 3, Gordon focuses on one particular moment within the talk:

\section{Extract 3:}

Gordon: I looked in the newspaper and they had an- the article said that the University of Leicester was looking for people with place-specific names whose maternal grandfather, I think it was.

Marc: Would probably have been paternal.

Gordon: Well, either. Because we fitted the bill on both counts had been born in the West Riding. And all my, as I say, all my immediate forebears, going back three generations, four generations, came from the West Riding. Yeah. So I suppose I must have sent an email. I can't remember now-yes I did, I sent an email and got a reply saying, yeah come along to the thing at the Folk Hall, y'know. Now that's a fairly 
Scandinavian sort of name, the Folk Hall. [Marc: (laughs)] Erm and uh yeah, it was good, I enjoyed that. Yeah.

Marc: Yes. And of course, only a short journey for you from here, yeah.

Gordon: Indeed, yeah, very handy, yeah. The obvious thing was that-I think it was Turi who was giving the initial talk. And she said that they were looking for names like, and she actually used my name, [surname] which I thought oh, that's- that's quite good, y'know.

The rhetorical organization of Gordon's story about his participation is interesting in that appears to be a deliberately mundane account that emphasises the contingent pattern of events that led to him being tested. In this way, Gordon avoids presenting himself as having a clear prior agenda or as being 'on a mission' to prove his existing beliefs around his ancestry. Instead, he describes a series of 'happy accidents' or 'good omens', from incidentally spotting the initial newspaper article, to the name of the venue, and subsequently his own name being cited as an example during Turi's talk. The cumulative effect of this rhetorical organization is to constitute a chain of small pieces of evidence or positive signs that prepare the way for the eventual delivery of the results of the testing. Gordon's story creates a narrative framework where he, in effect, is rhetorically 'inoculated' (Potter 1996) from the possibility of a negative result. If it turns out he is a Viking, it is one more happy accident, and if it turns out he is not, then he was never really looking to prove that anyway. Joe also focused on the significance of prior evidence:

\section{Extract 4:}

Joe: $\quad$ I listened to, you know, the introduction that we had and how we are linked and that sort of thing, but funnily enough one of the things that she was saying that genetics, how have even passed illnesses down, you know?

Marc: Yeah.

Joe: $\quad$ You know, which is quite funny because l've got what's called the sword hand that she was on about, you know, [Marc: Oh, the Dupuytrens, yeah, yeah] and when I actually came out I went to the missus, "Wow!" I said, "Look at that. I could be part Viking," you know, just through that, 'erm, but er, no I aren't that knowledgeable on about it and when I say just from what l've seen on the TV, and what I've read meself, you know what I mean? 
Joe describes himself as suffering from Dupuytren's Syndrome, a tissue disorder in the fingers sometimes referred to as 'sword hand' or 'Viking disease'. This was once widely assumed to be condition spread by Viking migration, but this has recently been called into question (e.g. Slattery, 2010). In Joe's account, it is the realisation of the significance of this sign, which is now gilded with scientific legitimacy following its inclusion in the talk, which underpins his sense of anticipation that he could actually be 'part Viking'. Much as with Gordon, we can see a story being built that prepares the way for the 'reveal' of the test results, but which also manages potential disappointment by downplaying prior motivations. Contrary to the concerns associated with the 'genetic astrology' metaphor, which might suggest that participants in genetic testing are looking simply for confirmation of existing views and take what they are looking from the process, here both participants, in common with Miles and Lawrence in the previous section, offer accounts which are rhetorically organized to anticipate and manage potential disappointment. Rather than looking for what they want to find, these participants appear to be open to hearing unexpected or unpredictable results.

\section{Making sense of the results: 'And I thought what the hell is this bit telling me'}

For a number of reasons, the process of returning results to participants was delayed. It also followed usual practice in returning results by mail rather than in person. As numerous studies have indicated (Hurst 2014; Nelson 2008; Tyler 2009) genetic data can be considered by participants as either too vague, or too complex to understand, with the result that they are difficult to incorporate into a narrative of ancestry and identity. At first glance, Ed seems to be experiencing precisely these difficulties:

\section{Extract 5:}

Ed: $\quad$ So I thought oh that could be good and but I didn't- and then I we- it's over 18 months ago this, and I thought that's the end of that, I'm not gonna hear any more, and then I got this letter out of the well, the e-mail out of the blue, that said thanks for your participation and there was that's that the ca- now I cannot makeunderstand one word of that. That is complete gobbledygook to me, is that. That is technically and academically way over my head. All, all that. That is meaningless. And I thought well what the hell is this bit telling me. And I went to the- it said you can, you test yourself by going on that, and I went to that and that didn't make at any bloody sense either.

Marc: Yeah, yeah, I've had a look at that website, it's not very easy to interpret 
Ed: So $\underline{m y}$ wife is very clever, she has a first class honours degree in, it's actually in food science and applied nutrition, but she's got the intelligence to go anywhere. So she went, I said this is one for you Laura, go and find something, I can't understand that I can't really, and I've been on that website and I can't make head nor tail of that, either. So, she went to another website. And she found that for me but thi- I am a G-M-two-hundred- I'm a G-M-201 haplogroup, whatever a haplogroup is, and that puts me in this lot. And I thought, well, that must be why they wouldn't have a word with me, because I'm one of the- I'm rare.

Ed vividly describes his initial confusion at receiving his results after a prolonged period time only to discover that the information contained is 'complete gobbledygook'. But what is interesting is the way he formulates the nature of the difficulty. It is not that the information is in principle too difficult to understand, rather that the technical language in which it is conveyed is a barrier to extracting its full meaning. He then goes on to narrate his efforts to make sense of his results, through enrolling his wife into the process and consulting various websites. Note again, that Ed's reference to his wife's academic achievements constructs his difficulties with the report as something that any educated individual would be likely to experience. The issue seems to be not of a general scientific literacy, but of the highly particular way in which genetic data is presented, requiring mediation by an expert. Eventually Ed and Laura 'crack' the problem and despite not knowing what the term 'haplogroup' means are able to incorporate the information on the G-M201 type into a narrative of 'rareness'. Here we can see that, the 'low-stakes' conditions notwithstanding, participants are prepared to put considerable effort into working with complex genetic data - Ed is not put off by his immediate confusion, nor does he appear to be seeking a simple or pre-ordained outcome from the testing. In the next extract, Howard describes a similar process of moving from initial confusion, to recruiting other information sources, to finally arriving at a tentative interpretation of his results:

\section{Extract 6:}

Howard: Well, my wife went online to try and work out, y'know, what my actual result meant. Erm and I'm still really struggling to get a detailed breakdown of all the facts and figures. And I know you can't advise on this but the frustration, I think, is that I'd like to know far more about what my result indicates. 'Cos all I know at the moment, from what my wife's found out, is that yeah, Scandinavian. Erm and before that, 
probably, northern barbarian tribes, which is maybe in a sense not a surprise. Explains the rugby league connection for a start, y'know. I mean so I'm frustrated that I cy'know, I can't I do- I don't have more really- real understanding of what this means. So I look forward to when the study is finally published. Which might make more sense of the limited information I've got about my own DNA, y'know.

Also enlisting the assistance of his wife, Howard arrived at the provisional conclusion that he has 'Scandinavian' ancestry. For many of the participants, this would be a 'good' result, indicating that prior beliefs in Viking ancestry were well-founded. But Howard appears to struggle to relate this information to his current identity. He first of all conventionalises the outcome in an ironic fashion, suggesting that a link to 'Northern barbarian Tribes' helps explain his 'rugby league connection'. (The invocation of a genetic link to 'warrior ancestry' to explain masculine 'fighting spirit' in physicallyoriented sport is also highlighted in Sommer (2012b, 123)). Beyond this, he is 'frustrated' that he lacks any 'real understanding of what this means'. As we have seen in other extracts, the information about genetic ancestry is not an end in itself, contra to notions of genetic essentialism, but is instead incorporated into a web of other identifications. In Howard's case the results raise more questions than they answer. The haplogroup information opens up a confusing picture of a remote and ill-defined past for Howard. It is a 'placeholder' rather than a clear 'marker' of identity, a point of departure rather than an origin. We can see a similar position adopted in the following:

\section{Extract 7:}

James: I haven't really made any sense of it, to be truthful. I've tried to, I $\underline{\text { did }}$ make an effort. I found a website where you could put erm let's just have a see if I can pull it up ... Erm that's me Haplogroup I-M170. Today it represents nearly one fifth of the population of Europe, it can be found in the majority of present day European populations, with peaks in northern and south-eastern Europe. Haplogroup I-M170 Y chromosomes, have also been found among some populations of the near east, the Caucasus, north east Africa and central Siberia. So I suppose looking at that I've not really studied that before. But this is Scandinavia, [Marc: yeah] isn't it.

Marc: So this is just looking at the map of erm Europe that comes with it.

James: That's better.

Marc: Yeah.

James: So in fact the greatest concentration of I-M170, fifty to seventy-five percent of people living in that area have got that [Marc: yeah, yeah] DNA group. So I 
think that pretty well nails it doesn't it. I know what threw me was this erm this oh, I don't see any reference

\section{[Conversation interrupted by attempting to find the right webpage]}

James: Right. No, I'm, I'm happy. I can't just see the - there was a reference to erm was he - what's he called. Some some m- Eurasian Adam". Came out of North Africa. And it sh- there was a big arrow shown on the map erm populating the whole of southern Europe. But no, that actually will do for me. I'm happy with that.

Whilst all of the interview data gives us some insight into the 'on the ground' practices of participants working with genetic data, this extract is particularly enlightening as it records the moment when one of the participants, James, realises the significance of his result as he shows Marc the various information sources he had previously consulted. James reads aloud the description on the distribution of the I-M170 haplogroup from a Wikipedia page, and after a brief pause recognises that this maps onto modern Scandinavia. With Marc's tacit encouragement, he appears to realise that his results do seem to confirm his desired Viking origins - 'I think that pretty well nails it'. But as with many other of the participants, James' reaction to learning of this outcome is somewhat downplayed ('that actually will do for me'). We would suggest that the reason for this is that James also engages with the broader genetic picture that underpins all haplogroups. The reference to 'Eurasian Adam' and links to North Africa, which had initially hampered his understanding of his results, mean that Scandinavia is no longer a clear stopping point for his genetic ancestry. If he is indeed of Viking descent, then by the same token he is also related to far broader genetic lineage that leads back to the dawn of human history, and links him to the rest of humanity more generally. We might say that the realisation is one of genetic 'de-essentialization'.

\section{What it means to be a 'Viking': 'Were they impressed by that?' 'Not really'}

The DNA analysis of the samples produced a range of results. Some participants were naturally disappointed that they did not get the results they had desired. However, in this last set of extracts we focus on participants who received confirmation that one strand of their male line ancestry carried a haplogroup associated with Scandinavia. It is here that we can see most clearly how 'low stakes' genetic information is put to use within families. For Lawrence, the results were vindication of a long-held belief:

\section{Extract 8:}

Marc: So what was your first reaction getting the results then [ 
Lawrence: $\quad$ Yes!! (laughs) [Marc: really? (laughs)] it was like you know, we've just scored a goal at Wembley (laughs).

Marc: $\quad$ Running around the garden with 'er [Lawrence: yeah] yes.

Lawrence: I was quite pleased actually but again, $y^{\prime}$ know, I still think it was, I

knew it.

Lawrence was clearly delighted with his results (despite the caveats which were presented throughout the testing process and within the results themselves). But what is of particular interest here is that his satisfaction comes as much from having what he claims to have already known confirmed as it does from the information about possible Viking ancestry. Again, this suggests that value of the information about haplogroup type comes from its incorporation into a pre-existing narrative framework. Instead of reducing identity to genetic ancestry, here genetics is folded back into an ongoing sense of identity that it extends and enhances rather than essentialises. This also has implications for the participant's family, as in the following extract:

\section{Extract 9:}

Rob: I have already told them that there's a massive chance that they are Vikings, they've already been told and it's fifteen and thirteen my two boys so I could imagine them wearing some type of loin cloth behind me (laughs) fight in York together. No, but yeah obviously if it's for me then obviously I'm passing that down in the history sense, yeah

Marc: $\quad$ And were they impressed by that?

Rob 'Erm, not really, they're teenagers, aren't they and they just wanted to get back on the Xbox, I'm sure if they created a game, a Viking game where it involved killing other people then I'm sure they'd be well up for it, yeah (laughs).

Rob immediately spread the good news of his probable Viking ancestry through his family. He considers this as a kind of 'gift' that he is able give to his children. The outcome of the first exchange - participation for knowledge - is then used as the basis for a second exchange where Rob offers his children an extended lineage into the deep past in exchange for a romanticized opportunity for father-son bonding (this we take to be the meaning of his fantasy of them fighting together as Vikings in York). However, Rob is very aware that this exchange is unequal, and that his children are unimpressed; however his positioning of this as being typical of teenagers holds out the promise that they may be more impressed in the future. As a placeholder of identity, potential Viking 
ancestry here holds together fantasies of family life rather than any clear benefit. A similar process is at work in the next extract:

\section{Extract 10:}

Helen: Well we gave [grandson] a laugh because when they did the reenactment this September when all the Norwegians came we said Nanny and Granddad were going to dress up and we were going to march down, that was at the cricket place, we were going to march down with flag so [grandson] says to us, are you really Nan, are you Granddad, so we says, oh yes, we'll be very smart with our Viking flag. We were only kidding, we didn't do it, did we, but it would have been a laugh if we had, wouldn't it? Marc: $\quad$ And have you had much reaction to the Viking flag when you've been taking it abroad or?

Helen: Well we've only done it the once haven't we [Harry: yeah 'cos its recent] because we only just [Harry: we only just got it] when we got the letter, we only just got it [Harry: well within] beginning of summer

Helen tells of how they used Harry's results as a way of connecting with their grandchildren. Through purchasing what they describe as a 'Viking flag' they are attempting - or potentially threatening - to perform a spectacle of Viking-ness for their family. Like the respondents in Sommer's (2012b) research, the identity accorded through genetic ancestry is here treated in a playful manner. Harry's results are a communicative resource whose primary value comes from the interactional work it affords with their grandchildren. There is no discernible gain in terms of their general social standing, and no immediate 'pay off' from having become part of an imagined community of modern Vikings. Clearly for participants like Lawrence, Rob and Harry, there is some cultural capital accrued, but this is secondary to their existing local identification with the North of England. Vikingness is a kind of additional resource, which whilst of value, can be happily expended in 'fun' activities such as displaying a flag. It is something that is 'interesting' rather than 'essential'.

\section{Population genetics in a context of applied genetic history}

Contemporary population genetics is conducted in the same social and cultural landscape as applied genetic history, with its concomitant emerging industry of commercial genetic testing. Indeed, the divisions between scholarly research and commercial exploitation (never clear-cut to begin with) are difficult for stakeholders in DNA testing to distinguish, with the selfknowledge offered by DNA testing increasingly framed as contributing to a broader knowledge of the history of humanity. Linked concerns about the social implications of genetic 
essentialization, and the lack of public understanding of population genetics leading to a form of 'genetic astrology', are therefore understandable.

However, taken at the level of the individual, it is arguable that current fears about the geneticization of social identities are rather too dramatic in imagining a sudden change, rather than a subtle shift in the nature of identity. Our concept of 'placeholder identity' speaks to the fundamental fluidity of identity, and the agency of individuals to shape their identities within the restrictions of available discursive resources. From our findings presented here, it is difficult to sustain an argument that knowledge of DNA results leads to a reification of identity, or the geneticization of the social to the exclusion of all else. Individuals are not judgmental dupes, in thrall to genetic information as a new and all-powerful source of knowledge that has an instantly transformative effect on identity. Furthermore, while 'genetic astrology' may be a succinct and evocative way of describing scientific concerns with commercial genetic ancestry testing products, it fortunately does not seem to entirely fit the self-conscious, critical manner in which participants in this study engaged with the results they received. Rather, new DNA information is incorporated into narratives of identity in a more subtle way; it becomes a placeholder, to be woven into a broader narrative of selfhood in relation to the past, in a dialogue with past personal or familial narratives, to be drawn upon at appropriate junctures, or to be retained until further information becomes available. While inescapably essentialist (insofar as they are based on the 'essence' of DNA), these strands of DNA are not essential to self-conception within these low-stakes conditions.

In stressing the agency of individuals with regard to DNA information, we are not preaching complacency. Nash (2015) has highlighted that individual agency in relation to the interpretation of DNA results does not immediately render them unproblematic: there is much that may remain troubling at a social level about the rise in genetic notions of kinship. However, such analyses would be informed by a more fine grained attention to the individual within 'biosocieties', both in 'high-stakes' and 'low-stakes' conditions. Arguably (and admittedly somewhat paradoxically), it may be the very mundanity of the placeholder identities we associate with low-stakes conditions that illustrates, and underpins the pervasiveness of the biosocial. Where genetic information is sufficiently well-recognised as an available discourse within society as to form the basis of a story to amuse grandchildren, or a yarn to be spun in the pub, then we may have entered the era of the biosociable, as well as the biosocial, where DNA has moved firmly out of the laboratory into the convivial spaces where narratives are retold and reinterpreted. 


\section{Acknowledgements:}

The authors gratefully acknowledge financial support from the Leverhulme Trust under Programme Grant F/00 212/AM.

The authors thank the anonymous reviewers, editors and colleagues for their helpful comments on an earlier version of this paper.

\footnotetext{
'It is worth noting that Author 3's caveats during the talk explaining that Dupuytren's Syndrome is not necessarily a marker of Viking descent have not been incorporated into Joe's narrative.

ii This is a reference to the person who bequeathed the original mutation on the $Y$ chromosome, around 90,000 years ago, the so-called ' $Y$-chromosomal Adam'.
}

\section{References}

Addyman, Peter V. 1990. "Reconstruction as Interpretation: the Example of the Jorvik Viking Centre, York." In The Politics of the Past, edited by Peter Gathercole and David Lowenthal. London: Unwin Hyman.

Balding, David, Mark Thomas, and Tabitha Innocent. 2013. Sense About Genetic Ancestry Testing. London: Sense About Science.

Billig, Michael. 1995. Banal Nationalism. London: Sage.

Bliss, Catherine. 2013. "The Marketization of Identity Politics." Sociology, 47(5), 1011-1025.

Brodwin, Paul. 2005. "Genetic Knowledge and Collective Identity." Culture, Medicine and Psychiatry, 29 (2), 139-143.

Duster, Troy 2011. "Ancestry Testing and DNA: Uses, Limits, and Caveat Emptor." In Race and the Genetic Revolution: Science, Myth, and Culture, edited by Sheldon Krimsky and Kathleen Sloan, 99-115. New York: Columbia University Press.

Fortier, Anne-Marie. 2012. "Genetic Indigenisation in 'The People of the British Isles'". Science as Culture, $21(2), 153-175$.

Golbeck, Natasha, and Wendy D. Roth. 2012. "Aboriginal Claims." In Biomapping Indigenous Peoples: Towards an Understanding of the Issues, edited by Susanne Berthier-Fogler, Sheila Collingwood-Whittick and Sandrine Tolazzi, 415-432. Amsterdam: Rodopi. 
Hamilton, Jennifer A. 2012. "The Case of the Genetic Ancestor." In Genetics and the Unsettled Past: the Collision of DNA, Race and History, edited by Keith Wailoo, Alondra Nelson and Catherine Lee, 266-278. London: Rutgers University Press.

Harris, Anna, Sally Wyatt,, \& Susan E. Kelly, 2013. "The Gift of Spit (and the Obligation to Return it)." Information, Communication \& Society, 16 (2), 236-257.

Hurst, Martyn Jeffrey 2014. "'Putting the flesh on the bones': Evidencing and imagining genealogical connections with family historians in Northumberland, County Durham, and Tyne and Wear." PhD, Durham University. Retrieved from http://etheses.dur.ac.uk/10546/

Ingold, Tim and Gisli Palsson. (eds.) 2013 Biosocial Becomings: Integrating Social and Biological Anthropology. Cambridge: Cambridge University Press.

Jobling, Mark, Rita Rasteiro and Jon Wetton. 2015. "In the Blood: The Myth and Reality of Genetic Markers of Identity.", Ethnic and Racial Studies, this volume.

Jobling, Mark, Edward Hollox, Matthew Hurles, Toomas Kivilsid and Chris Tyler-Smth. 2013. Human Evolutionary Genetics, $2^{\text {nd }}$ ed. London: Garland Science.

King, Turi E., \& Mark A. Jobling 2009. "What's in a Name? - Y Chromosomes, Surnames, and the Genetic Genealogy Revolution." Trends in Genetics, 25 (8), 351-360.

Halewood, Chris and Kevin Hannam. 2001. "Viking Heritage Tourism: Authenticity and Commodification." Annals of Tourism Research, 28 (3), 565-580.

Meloni, Maurizio 2014. "How Biology became Social, and what it means for Social Theory." The Sociological Review, 62 (3) 593-614.

Morning, Ann. 2014. “And You Thought We Had Moved Beyond All That: Biological Race Returns to the Social Sciences." Ethnic and Racial Studies, 37 (10), 1676-1685.

Nash, Catherine. 2004. "Genetic kinship." Cultural Studies, 18 (1), 1-33.

Nash, Catherine. 2008. Of Irish descent : origin stories, genealogy, and the politics of belonging . Syracuse, N.Y.: Syracuse University Press.

Nash, Catherine. 2015. Genetic Geographies: The Trouble With Ancestry. Minneapolis: University of Minnesota Press.

Nelson, Alondra. 2008. "Bio Science: Genetic Genealogy Testing and the Pursuit of African Ancestry." Social Studies of Science, 38 (5), 759-783.

Nordgren, Anders, and Eric T. Juengst, 2009. "Can genomics tell me who I am? Essentialistic rhetoric in direct-to-consumer DNA testing." New Genetics and Society, 28 (2), 157-172.

Phelan, Jo C., Bruce G. Link, Sarah Zelner,, \& Lawrence H. Yang. (2014). “Direct-to-Consumer Racial Admixture Tests and Beliefs About Essential Racial Differences." Social Psychology Quarterly, $77(3), 296-318$. 
Potter, Jonathan. 1996. Representing Reality: Discourse, Rhetoric and Social Construction. London: Sage.

Rose, Nikolas. 2013. "The Human Sciences in a Biological Age." Theory, Culture \& Society, 30 (1), 334.

Schramm, Katharina, David Skinner and Richard Rottenburg. 2012. "Ideas in Motion: Making Sense of Identity Politics and the New Genetics." In Identity Politics and the New Genetics, edited by Katharina Schramm, David Skinner and Richard Rottenburg, 1-29. Oxford: Berghahn Books.

Scully, Marc, Turi King and Steven D Brown. 2013. "Remediating Viking Origins: Genetic Code as Archival Memory of the Remote Past." Sociology, 47 (5), 921-938.

Simpson, Bob. 2000. "Imagined Genetic Communities: Ethnicity and Essentialism in the Twenty-First Century". Anthropology Today, 16 (3), 3-6.

Slattery, David. 2010. “Review: Dupuytren's Disease in Asia and the Migration Theory of Dupuytren's Disease". ANZ Journal of Surgery, 80 (7-8), 495-499.

Sommer, Marianne. 2012a. ""It's a Living History, Told by the Real Survivors of the Times - DNA". Anthropological Genetics in the Tradition of Biology as Applied History." In Genetics and the Unsettled Past: the Collision of DNA, Race and History, edited by Keith Wailoo, Alondra Nelson and Catherine Lee, 225-246. London: Rutgers University Press.

Sommer, Marianne 2012b. "'Do You Have Celtic, Jewish or Germanic Roots?' Applied Swiss History before and after DNA." In Identity Politics and the New Genetics: Re/Creating Categories of Difference and Belonging, edited by Katharine Schramm, David Skinner and Richard Rottenburg, 116-140. Oxford: Berghahn Books.

Thomas, Mark 2013. "To Claim Someone has 'Viking Ancestors' is no better than Astrology", The Guardian, February 25. Retrieved from http://www.guardian.co.uk/science/blog/2013/feb/25/viking-ancestors-astrology

Townend, Matthew. 2014. Viking Age Yorkshire. Pickering: Blackthorn Press.

Tutton, Richard. 2002. "Gift Relationships in Genetics Research." Science as Culture, 11 (4), 523-542.

Tutton, Richard. 2004. “"They Want to Know Where They Came From”: Population Genetics, Identity, and Family Genealogy." New Genetics and Society, 23 (1), 105-120.

Tyler, Katharine. 2009. "Whiteness Studies and Laypeople's Engagements with Race and Genetics." New Genetics and Society, 28 (1) 37-50.

Williams, Sloan R 2005. “Genetic Genealogy: The Woodson Family's Experience.” Culture, Medicine and Psychiatry, 29 (2), 225-252. 
